\title{
UMA CENA RELIGIOSA NA PAISAGEM AMAZÔNICA: A NARRATIVA DE TAMAR E AMON NA POESIA DE JOÃO DE JESUS PAES LOUREIRO
}

\section{A RELIGIOUS SCENE IN THE AMAZONIAN LANDSCAPE: THE NARRATIVE OF TAMAR AND AMON IN THE POETRY OF JOÃO DE JESUS PAES LOUREIRO}

\author{
Douglas Rodrigues da Conceição ${ }^{1}$
}

RESUMO: Partindo da poesia de João de Jesus Paes Loureiro, importante nome da cena literária de dicção amazônica, e sob a ótica teórica de Gaston Bachelard (1942), Gérard Genette (1982) e Mircea Eliade (1991), o presente artigo analisa a ostensiva presença da narrativa de Tamar e Amon no Cântico XVII de Porantim (1978), obra que em 1985 passaria a integrar a trilogia então chamada de Cantares Amazônicos. Tem-se como pressuposto que a poética de João de Jesus Paes Loureiro, que no Cântico XVII de Porantim desagua na criação de um cenário sacro-amazônico para Tamar e Amon, se constitui sob a convocação do imaginário amazônico das águas dos rios, das escrituras do AT (2Sm 13), da poesia hispânica de Federico García Lorca e do mito erótico-amazônico de Tambatajá.

PALAVRAS-CHAVE: Amazônia; poesia; Tamar e Amon; Tambatajá

ABSTRACT: Starting from the poetry of João de Jesus Paes Loureiro, relevant name in the literary scene of amazonian diction, and underneath the theoretical light of Gaston Bachelard (1942), Gérard Genette (1982) e Mircea Eliade (1991), this current article analyses the ostensible presence of Tamar and Amon's narrative in the labor Cântico XVII de Porantim (1978), which in 1985 would incorporate the trilogy named Cantares Amazônicos. It is supposed that the poetry of João de Jesus Paes Loureiro, which in Cântico XVII de Porantim pours into a sacral amazonian scenario, was formed under the amazonian announcement of rivers' water, scripiture of AT (2Sm 13), the Hispanic poetry of Federico García Lorca and the amazonian erotic myth Tambatajá.

KEIWORDS: Amazon; poetry; Tamar e Amon; Tambatajá

\footnotetext{
${ }^{1}$ Doutor em Ciências da Religião pela UMESP, com Pós-Doutorado na Université Paris Nanterre. Professor do PPG em Ciências da Religião da UEPA. Coordena o Laboratório Interdisplinar de Pesquisas em Religião e Cultura. Pesquisa com apoio CAPES, UEPA, UFPA, UMESP, Pontificia Universidad Católica de Chile e Sorbonne Université.

${ }^{2} \mathrm{O}$ presente texto é parte dos primeiros resultados do projeto de pesquisa intitulado "Imaginários religiosos na Amazônia oriental", cujo desenvolvimento se dá no âmbito do PROCAD-Amazônia/CAPES. Este texto é dedicado ao poeta João de Jesus Paes Loureiro.
} 


\section{Introdução}

Num artigo publicado em 2005, Raymundo Heraldo Maués, um dos principais antropólogos da Amazônia, ressaltou que antes mesmo do trabalho seminal realizado por Eduardo Galvão, a vida religiosa do caboclo amazônico já "tinha sido estudada e abordada por ficcionistas e folcloristas" (MAUÉS, 2005, p. 259). Dois anos mais tarde, Maués consagraria um novo texto à obra Marajó, de Dalcídio Jurandir. Neste trabalho, o olhar etnográfico do antropólogo paraense acerca da religião e da medicina popular no contexto amazônico partiria então de um romance. A preocupação de Maués era inequívoca: os estudos de religião na Amazônia não poderiam passar sem conferir a devida atenção à literatura forjada neste complexo contexto sociocultural.

Para o antropólogo paraense, o romance Marajó ganhara lugar em suas reflexões não só em razão da riqueza das descrições que comporta - certamente referindo-se à exuberância da vida natural e cultural na Amazônia -, mas também porque enxergara certa proximidade ou mesmo equivalência entre o trabalho dos etnógrafos e o dos romancistas, dos contistas, dos poetas e dos críticos literários.

\footnotetext{
Marajó, de Dalcídio Jurandir, combinando esse importante elemento folclórico com a imaginação ficcional do autor, traz ao mesmo tempo um vívido retrato da sociedade marajoara e paraense do início do século XX - enfatizando, basicamente, a estrutura social regional e a injustiça e o arcaísmo da dominação de classe -, mas ao mesmo tempo retratando, com vívidas cores, a cultura popular, o catolicismo das festas, das devoções e das folias populares, a pajelança, o espiritismo, as influencias africanas, a atividade dos vaqueiros e pescadores, as práticas desonestas dos poderosos, a violência contra os que não se submetem à dominação, a medicina popular, a música, a dança, a sexualidade, as relações de gênero, os riscos nas relações sociais e com a natureza, a vida, enfim, em toda a sua plenitude. E, tudo isso, com uma tessitura narrativa de mestre e com uma beleza poética invejável, no mesmo nível da melhor literatura brasileira e universal (MAUÉS, 2007, p. 158-159).
}

Mirar a criação artística como caminho para uma abordagem dos aspectos religiosos da Amazônia evidencia antes que a experiência nativo-existencial dos escritores se coloca à disposição de um esforço compreensivo de sua própria cultura. Admitindo tal pressuposto - no lugar da pretensa objetividade do campo, por supostamente permitir um tipo preciso de transcrição da cultura por parte do observador - Maués reivindica a compreensão das expressões religiosas amazônicas por meio da tradução de um quadro sociocultural que a literatura realiza. Mirar as expressões literárias amazônicas como ponto de partida, insistimos, significa reconhecer que a situação existencial de ficcionistas e de poetas nativos é uma chave indispensável para a decifração da vida religiosa na Amazônia. Em relação ao mundo 
amazônico, profundamente híbrido e intercultural, a criação literária (prosa ou poesia) seria então um repositório de mitos, imaginários, moldura impressionista da exuberância da natureza, memória de resquícios e traços de outras culturas, mescla de tudo isso muitas vezes num só tecido. É, portanto, a presença de uma narrativa religiosa na poesia de dicção amazônica a principal preocupação do presente texto. Assim, o artigo em questão pretende discutir a ostensiva convocação da narrativa de Tamar e Amon feita pelo Cântico XVII, da obra Porantim (1978), da autoria de João de Jesus Paes Loureiro, um dos nomes mais expressivos da criação literária na Amazônia.

\section{A poesia de dicção amazônica e a convocação de um texto bíblico}

A percepção mais imediata do que nomeamos Amazônia é quase sempre derivada da inigualável e sublime expressão natural que lhe é tão peculiar. Mescla de águas e matas, o propriamente amazônico não se esgota, é claro, na beleza da sua paisagem natural - porque o físico e o humano performam evidentemente a Amazônia em um espaço cultural riquíssimo mas é essa paisagem a porta principal e também a guia mestra neste imenso labirinto de águas. Ainda que o trabalho de poetas e ficcionistas, por exemplo, possa ser comparado ao trabalho dos etnógrafos e de outros cientistas sociais, tal como reivindica Maués, a preocupação dos escritores com suas formas de expressão é também de outra ordem, visto que tal preocupação implica necessariamente em uma evidente atenção artística à matéria prima que compõe tais formas expressivas. Como seria possível admitir que os poetas, os romancistas ou os contistas declinam do proposito artístico ao por em movimento o seu processo criativo? Em sua função propriamente artística, o poema, o romance ou o conto não podem ser reduzidos tão somente à descrição objetiva de "um vívido retrato da sociedade [...]" (MAUÉS, 2007, p. 159) ou da cultura. Se esse ofício pode ser atribuído ao escritor, categoria tão cara a Roland Barthes ${ }^{3}$, concebemos que suas respectivas formas de expressão literária são antes oriundas da imaginação poética e da criação artística e esta é uma das linhas mestras da nossa reflexão aqui. Os escritores, de modo geral, não se expressam em nome da etnografia ou das ciências sociais. É por este caminho que procuramos pensar o amazônico na poesia de João de Jesus Paes Loureiro, bem como a convocação que ele faz da religião no seu tecido poético.

A compreensão do amazônico a partir do que lhe dá existência linguística, isto é, a sua literatura, os seus mitos, os seus imaginários, a sua poesia, por exemplo, tem na exuberância do

\footnotetext{
${ }^{3}$ Referimo-nos, aqui, ao capítulo Escritores e escreventes, da obra Crítica e verdade. Cf. BARTHES, Roland. Crítica e verdade. 3. ed. São Paulo: Perspectiva, 2007.
} 
elemento natural sua principal matéria prima. Paulo Nunes, um dos grandes estudiosos da literatura de Dalcídio Jurandir, grande romancista paraense, procurou compreender a literatura do autor dos romances Marajó e Chove nos campos de Cachoeira a partir do conceito de aquonarrativa. Para Nunes (NUNES, 2007, p. 105), na literatura dalcidiana predomina a construção de cenas, personagens e situações ancoradas na paisagem líquida da Amazônia. Esta precisa percepção de Nunes - que pode ser alçada para além da beleza da romanesca dalcidiana - lança-nos ao epicentro da onto-cosmo-logia amazônica. O elemento água é o elemento primordial nas antigas imagens cosmogônicas, mas é também o elemento primordial do propriamente amazônico. “A água”, lembra-nos Mircea Eliade (ELIADE, 2010, p. 155), “é germinativa, fonte de vida, em todos os planos da existência". A passagem da matéria à linguagem, por meio da criação poética - por Bachelard chamada de "documentos poéticos" (BACHELARD, 1942, p. 7) - evidencia um tipo de imaginação material da água. Portanto, a criação poética - que é materializada pelo poema - estaria intimamente ligada a um tipo de aproveitamento estético da matéria água.

Poeta, ficcionista, dramaturgo e teórico da cultura Amazônia, João de Jesus Paes Loureiro é um dos grandes nomes das letras desta imensa 'Pátria da água'4 . Nascido em 1939, em Abaetetuba, cidade da Mesorregião do Nordeste Paraense, Paes Loureiro, em sua vasta antologia, recolhe poemas, romances, peça teatrais, textos de crítica da cultura, entre os outros escritos. Interessa-nos aqui justamente um emblemático poema de Porantim $^{5}$, obra de 1978. Em 1985, Porantim, ao lado de Deslendário, de 1981, e Altar em chamas, de 1983, comporia a trilogia intitulada Cantares amazônicos (1985).

Sendo a dimensão cósmica e mítica do elemento água um traço fundamental nos imaginários amazônicos e nas criações artísticas deste universo cultural e natural, onde os rios, os igarapés, os paranás e as chuvas ocupam quase sempre o primeiro plano, o poema de Paes Loureiro encontra nela [na água] a sua matéria artística fundamental, isto é, a sua própria substância. Como já foi dito, o poema sobre o qual nos debruçaremos é o Cântico XVII, de Porantim. Em sua dimensão mais ostensiva, o poema evoca a narrativa de Tamar e Amon, que aparece em 2Sm, 13, 1-39, no Antigo Testamento da Bíblia. Entre outros elementos, o vocábulo

\footnotetext{
${ }^{4}$ A expressão Pátria da água se deve ao poeta amazonense Thiago de Mello.

${ }^{5}$ A obra Porantim, de 1978, é composta por 43 poemas chamados de cânticos. Reproduziremos, abaixo, a epígrafe que abre Porantim, na qual o poeta - recorrendo a obra 'Os índios Maué', de Nunes Pereira - apresenta os significados do vocábulo que dá nome ao seu livro de poemas:

'... a peça etnográfica PORANTIM, encontrada entre os índios Maué, do lugar Terra Preta, no alto do Rio Andirá, Estado do Amazonas, Brasil, é um 'remo mágico' e uma 'arma de guerra' ao mesmo tempo. Nele se acham inscritos os signos que narram a tradição lendária da tribo, desde a antiga terra de origem - Noçoquém - lugar de felicidade perdida. Segundo a tradição, o remo mágico que é Porantim, vaio, pelo tempo à fora, das mãos do Tucháua Uaçiri-Post, que passou às mãos do Tucháua Muratu, que, morto o deixou para seu filho...'
} 
Cântico evoca de súbito, por uma ação paratextual e metatextual (GENETTE, 1982), a atmosfera erótica do livro bíblico de Cântico dos Cânticos. Tal evocação se intensifica, é claro, com a presença da personagem Amon, símbolo do desejo incontrolável e incestuoso no ambiente narrativo do $\mathrm{AT}^{6}$.

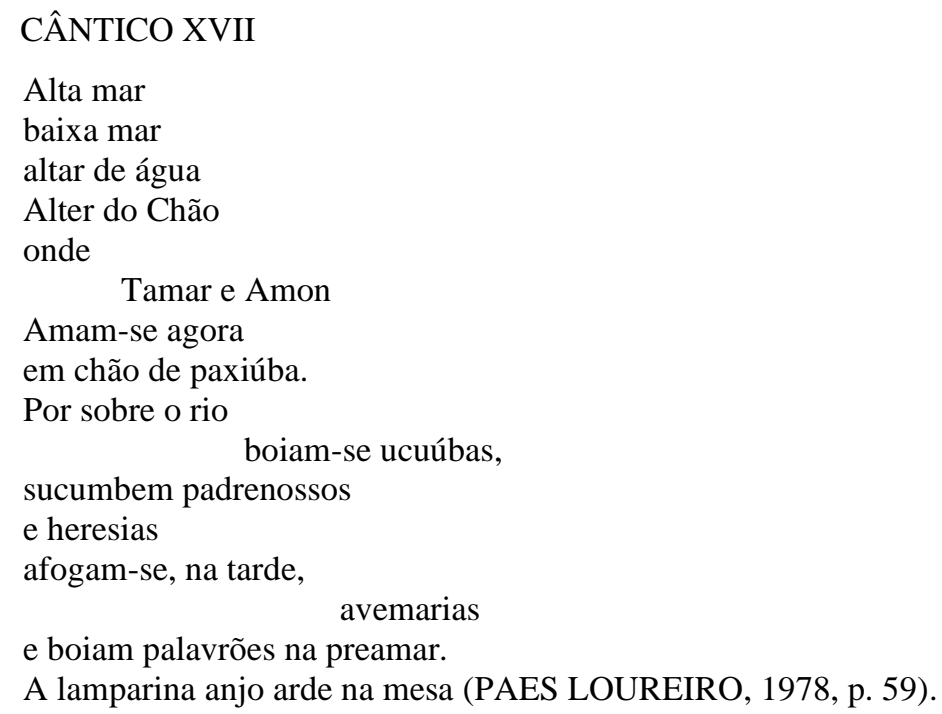

Os versos em questão se apresentam como uma expressão da imaginação material (BACHELARD, 1942) criadora que conjuga, na superfície do poema, num primeiro instante, uma transfiguração poética da paisagem amazônica, do elemento água e de uma narrativa bíblica do AT, o que aponta para a existência de uma dinâmica ordem metatextual entre o poema e o texto bíblico. A porta de entrada para o Cântico XVII - considerando os três primeiros versos - evoca o movimento das águas amazônicas em seu incessante devir.

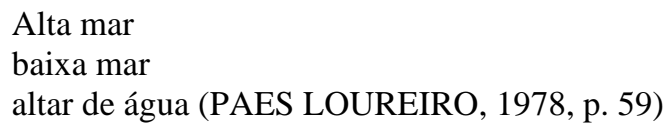

O poema traz para o primeiro plano um dos elementos fundamentais do imaginário amazônico: a água dos rios. Numa espécie de estética impressionista, a configuração poética da água se perfaz sob a captura do momento presente que o poema quer revelar. O poeta evoca o rio, isto é, as águas que sobem (na cheia/preamar) e que descem (na vazante/baixa-mar) e que são protagonistas deste "imenso e solene anfiteatro amazônico” (PAES LOUREIRO, 1995, p. 121): eis a constituição do cenário. Os versos “Altar mar/ baixa mar”, no poema, expressam o

\footnotetext{
${ }^{6}$ Assim aparece Amon nos dois primeiros versículos de 2Sm 13: 1Eis o que aconteceu depois disso: Absalão, filho de Davi, tinha uma irmã que era bonita e chamava Tamar, e Amnon, filho de Davi, se apaixonou por ela. 2Amnon se atormentou a ponto de adoecer por causa da sua irmã Tamar, porque ela era virgem e ele não via nenhuma possiblidade de lhe fazer algo. Cf. BÍBLIA DE JERUSALÉM. São Paulo: Paulus, 2000.
} 
movimento cósmico por excelência da Amazônia dos rios, isto é, a incessante oscilação das águas. Esta paisagem aquática "evanescente” (STOLL et al., 2019, p. 28), invariavelmente em profundo devir, e que é evocada pelo poeta e que abre o poema, vista pelo prisma da oscilação das águas nas planícies amazônicas, simboliza a dinâmica instauradora do ritmo da vida no seio amazônico - quer seja no decurso de um dia (preamar/ baixa-mar), quer seja na dimensão cíclica das estações (estação seca/ estação chuvosa) - demarcando assim uma órbita cíclicotemporal própria da região Norte. O rio ocupa o primeiro plano nesta paisagem amazônica e nela repousam Tamar e Amon.

A dialética das imagens dos rios, poeticamente configurada, faz com que este ente da paisagem amazônica, que também "é rua"7 "igarapé"8 e "pão líquido", torne-se no poema de Paes Loureiro - num poético devir - um “Altar de água”. O verso em epígrafe metaforiza e enfatiza a sacralidade que o poema reivindica para a cena originária poeticamente tecida. $\mathrm{O}$ sema "Altar" reivindica para o rio a condição de topos sagrado. O poema prossegue com o verso "Alter do chão". O poeta de Porantim nada rejeita. Explora a semelhante sonoridade dos vocábulos “Altar” e “Alter” em sequência de versos e vai além. À primeira vista, o sema "Alter do chão" nos remete ao distrito paraense situado na Mesorregião do Baixo Amazonas e que pertence ao município de Santarém. A exuberância do distrito de Alter do chão, entre outras singularidades, está vinculada à coloração quase turquesa e cristalina de suas águas, sobretudo, na época das águas baixas, quando as "praias de rios" se formam ao longo do rio Tapajós. $\mathrm{Na}$ fronte de Alter do chão, exatamente no período das águas baixas, emerge uma pequena ilha popularmente conhecida como "Praia do amor". Os versos "altar de água/ Alter do chão" evocam, assim, a um só tempo, uma fixação mítico-espacial para Tamar e Amon, agora enredados nas "malhas" das águas amazônicas. O verso "Alter do chão" evoca igualmente a tessitura mesma da criação artística, porque o cenário da poesia é amazônico, mas Tamar e Amon não. "Alter do chão" quer dizer de outro chão. De que chão? Tamar e Amon deslizam, portanto, de outro chão poético-narrativo e passam a habitar "o solo" da poesia Amazônica pelas mãos do poeta.

\section{No poema, outros poemas}

\footnotetext{
${ }^{7}$ Paulo André Barata e Ruy Barata, dois grandes nomes da música paraense, compuseram uma belíssima canção nomeada Este rio é minha rua. A primeira estrofe diz: "Este rio é minha rua/ Minha e tua mururé/ Piso no peito da lua/ Deito no chão da maré [...]".

${ }^{8} \mathrm{Na}$ língua tupi quer dizer caminho da canoa.

${ }^{9}$ Metáfora evocada por Paes Loureiro e que está presente no poema de abertura da obra Deslendário:

"Rio que já não corre puro em meus poemas/ coroado de espumas, mururés./ Rio, pão líquido, trigal de escamas,/ que alimentou de lendas o poemário [...]” (PAES LOUREIRO, 1981, p. 12).
} 
[...] onde

Tamar e Amon

Amam-se agora (PAES LOUREIRO, 1978, p. 59)

A narrativa de Tamar e Amon, como já dissemos, está presente no livro segundo de Samuel. O texto bíblico narra a história da incontida e incestuosa paixão de Amon por Tamar, sua irmã. A sinuosidade da poesia de Paes Loureiro nos convoca a mirar aquilo que Genette (1982) chamaria de hipotexto, qual seja, o já aludido texto do Antigo Testamento, 2Sm 13. É preciso antes considerar, em expressão própria do autor de Deslendário, que uma poética da Amazônia - essa Amazônia que segundo Ana Pizarro seria uma construção discursiva e que "es ocupada sobre todo por la imaginación” (PIZZARRO, 2005, p. 62) e que está refletida no poema de Paes Loureiro - não se perfaz sem que a percebamos como um espaço de hibridações culturais. No canto de Tamar e Amon, ao costurar tecidos diversos, o aedo se apresenta como uma espécie vetor de propagação de mitos de outros chãos.

O verso "amam-se agora", do Cântico XVII, interpela o texto bíblico no que concerne ao ato que desencadeia o elemento trágico em $2 \mathrm{Sm} 13$, que é a interdição do amor erótico entre irmão e irmã. A intransitividade da forma flexionada "amam-se", que no poema, como se vê, apresenta-se no tempo presente e que é acompanhada pelo advérbio de tempo "agora", põe em suspenso, assim interpretamos, o interdito expresso e transmitido pelo mito bíblico. $\mathrm{O}$ deslocamento do mito de Tamar e Amon para o Cântico XVII, de Porantim, dispensa claramente o epílogo da narrativa bíblica. Tamar e Amon "amam-se agora" e amar-se-ão todas as vezes em que o poema for revisitado, visto que o tempo do verbo amar, no poema de Paes Loureiro, reconfigura toda transitividade (ato e consequência) da transgressão cometida pelo Amon de 2Sm 13. Não há nos versos de Paes Loureiro culpabilidade alguma para Amon e Tamar.

Esta reconfiguração tal como a postulamos e que só seria perceptível por meio dos versos do poema de Paes Loureiro - posto que o Amom bíblico se distancia daquele que figura no Cântico XVII - nos leva a pensar que no lugar do hipotexto bíblico - ainda que 2Sm 13 permaneça como hipotexto por excelência para a cultura literária ocidental - um outro hipotexto possa ser mirado. Seria então preciso compreender melhor se a passagem da narrativa à poesia só poderia de fato ser depreendida da nítida relação inter e hipertextual (GENETTE, 1982) que conecta o texto bíblico aos versos do poema de Paes Loureiro. Objetivamente não se pode negar que o Amon da aquopoética de Porantim nos remete ao Amom bíblico. Mas, como bem assinala os versos do Cântico XXVIII, de Porantim: "no mito / outro mito". Postulamos, portanto, que 
a Bíblia está sim ostensivamente presente no Cântico XVII, de Porantim, mas também se apresenta na obra de Paes Loureiro o poema Thamar e Amnón, de Federico García Lorca, que está coligido ao chamado Romanceiro gitano do poeta andaluz. O que nos fez ir até Lorca e em movimento contínuo pensar possíveis conexões da poesia de Paes Loureiro com a do poeta espanhol foi exatamente uma entrevista conduzida pelo poeta paraense. O interlocutor de Paes Loureiro era Ariano Suassuna, grande poeta, romancista e dramaturgo paraibano. Alguns trechos da entrevista indicarão as pistas que seguimos.

Paes Loureiro: Todos nós escrevemos a partir do que vivemos, mas também do que lemos. Sua obra é, ao mesmo tempo, de criação e de pensamento. Como se dá a sua escrita, como ela passa por essa relação de vivência e reflexão? Certamente a um diálogo da sua obra com obras marcantes para você e que também são marcantes para a cultura ocidental.

Ariano Suassuna: Novamente faço uma ressalva: quando eu falar aqui em determinados autores, não estou me colocando à altura deles. Estou somente dizendo que pertenço à mesma família.

Paes Loureiro: [....] Mas há um poeta espanhol pelo qual você nutre grande admiração e, creio, deve ter se banhado um pouco na obra dele: García Lorca.

Ariano Suassuna: Lorca. Demais. Exerceu uma influência fundamental em mim. Fundamental. Foi Lorca que me libertou de um temor que eu tinha: não gosto da poesia falada. Gosto poesia baseada em imagens. E não gosto da poesia muito clara nem muito lógica [...]. Pois bem, quando era muito moço, li um poema de Lorca e quando terminei pensei: não entendi uma palavra desse poema, mas é muito bonito [...] é do livro Romanceiro cigano [...].

Paes Loureiro: É incrível.

Ariano Suassuna: E você veja, o grande poeta espanhol pegou o romanceiro popular da Península Ibérica, cigano, e fez seu grande livro.

Paes Loureiro: Há pouco falávamos dessa questão do trânsito entre a tradição popular e o erudito. Há um poema dele, desse livro Romanceiro cigano, que é o "Tamar e Amon" e que fala de um incesto. Esse poema vem da tradição judaica, aparece na Bíblia, e Lorca trata daquela forma belíssima. Já vi isso no Brasil em trabalho de cantoria de cordel, retornando ao popular.

Ariano Suassuna: Tomado do Velho Testamento.

Paes Loureiro: Sim, mas é o itinerário de um tema pela poesia que faz esse percurso no tempo. É uma coisa maravilhosa.

Ariano Suassua: O último verso de "Tamar e Amon" é uma dramaticidade e de uma tristeza sem par. Ele diz que quando Davi soube da história, com as tesouras cortou as cordas da harpa (CONVERSA SOBRE ARTES, 2014, p. 28-34).

Abaixo, algumas estrofes do referido poema de García Lorca.

\section{Thamar e Amnón}
A lua gira no céu
por sobre as terras sem água,
Enquanto o verão semeia
Rumores de tigre e chama.
[...]
Thamar estava sonhando
em sua garganta pássaros
ao som de pandeiros frios
e de enluaradas cítaras.
Sua nudez no beiral,
Agudo norte de palma, 


\section{Pede copos a seu ventre}

e granizo a suas costas.

Thamar estava cantando desnuda lá no terraço.

[...]

Amnón, delgado e concreto,

lá na torre a contemplava,

[...]

Sua nudez resplendente

no terraço se estendia,

com um rumor entre dentes

de flecha recém-cravada.

[...]

Às três e meia Amnón

estendeu-se sobre a cama.

A alcova inteira sofria.

[...]

Thamar entrou silenciosa

na alcova silenciada,

[...]

Deixa-me tranqüila irmão

São teus beijos no meu dorso

Abelhas e ventozinhos

em duplo enxame de flautas.

[...] (GARCÍA LORCA, 1973, p. 59-61).

À primeira vista, os poetas escondem o jogo de suas poéticas, mas anseiam, sabemos, pelo deslindamento de suas tramas artísticas. É preciso dizer que a publicação da referida entrevista é datada de 2014, enquanto Porantim aparece em 1978. Paes Loureiro não evoca gratuitamente o poema de Lorca. Na superfície do Cântico XVII, o poeta parece nos oferecer, por meio do seu Amon e de sua Tamar, a incestuosa e violenta narrativa bíblica. Embora tenha dito a Ariano Suassuna [na entrevista] que o poema "fala de um incesto" [em referência ao poema andaluz], em nossa ótica seria a suspensão do interdito o elemento que deslinda o fio que conecta o poema amazônico de Paes Loureiro ao poema gitano de García Lorca. Sob "A lua que gira no céu", a Thamar e o Amnón de García Lorca, ambos atravessados por "flecha recém-cravada", na "alcova silenciada", cedem à misteriosa e avassaladora irrupção de Eros em seus corpos, sem deixar o mais ínfimo rastro de culpa ${ }^{10}$.

Paes Loureiro e García Lorca se aproximam, entre outros aspectos, porque em ambos os poemas a regência da vida parece ser realizada em íntima conexão cósmica com elementos da natureza. Em Lorca temos um tipo regime lunar (ELIADE, 1991), que preside o rito gitano, por assim dizer: "A lua gira no céu [...]"; em Paes Loureiro, a regência é eminentemente realizada pelo

\footnotetext{
${ }^{10}$ Digna de destaque é a observação que Eladio García C. faz acerca da poética de García Lorca ao retomar a narrativa de Tamar e Amon: “[...] Los gitanos y en general el pueblo andaluz, cantan el 'Romance de Tamar y Amnón' llamando a Tamar Altas Mares. De Tamar Tamare, de Tamare Altamare y de Altamare, Altas Mares, que es mucho más bonito”. Cf. GARCÍA C., Eladio. Interpretación del romance Thamar y Amnón y sus incrustes gongorinos. Revista Chilena de Literatura, Santiago, 1980/1981, p. 26. A primeira estrofe do poema de Paes Loureiro parece estabelecer alguma conexão com esta tradição onomástica cigana que circunda o nome Tamar: "Alta mar/ baixa mar/ altar de água/ Alter do Chão/ onde [...]”.
} 
regime das águas. Essa dimensão cósmico-pictural notadamente presente em cada um dos poemas pode ser compreendida como estratégia poética de recriação de uma cena originária (in illo tempore).

Revolvendo os primeiros versos do Cântico XVII, de Porantim, quais sejam, "Alta mar/ baixa mar", temos na imagem projetada por eles a representação poética do ciclo das águas amazônicas. Essa evanescente cosmologia aquática, que ordena a paisagem e que lança o humano amazônico numa complexa semiosfera, permite ao poema recuperar a "imagem exemplar de toda criação", que para Eliade seria a imagem da "ilha que subitamente se manifesta" (ELIADE,1991, p. 151). Tão presente nas regiões onde há o predomínio das matas úmidas, a paxiúba apresenta-se como um tipo de vegetação que vive tanto sob as águas, na época das cheias, quanto fora delas, na época da seca. Tamar e Amon do Cântico XVII, de Porantim, pertencem - assim sugere o poema - a uma cosmologia aquática e telúrica. A aparição das raízes da paxiúba - que no poema torna-se matéria prima do leito erótico de Tamar e Amon [“amam-se agora/ em chão de paxiúba"] - só é possível na dimensão cíclicocosmológica de imersão e emersão desta espécie vegetal nas águas amazônicas. É a partir de uma paisagem amazônico-paradisíaca que o poema - sendo um tipo de documentação poética da imaginação (BACHELARD, 1942) - expressa certa "nostalgia do paraíso" (ELIADE, 1991).

O Cântico XVII inscreve, à exaustão, Tamar e Amon numa cosmologia aquáticoamazônica. Assim diz o poema: "Por sobre o rio/ boiam-se ucuúbas". Diante do evanescente e incessante movimento de subida e descida das águas dos rios ["Por sobre o rio"] - seja na ordem do dia (preamar/ baixa-mar) ou na das grandes estações (época das cheias/ época da seca) - a paisagem que evanesce cede lugar a uma outra. Com as águas altas - na estação das chuvas a paxiúba submerge, passa a habitar a profundeza do rio, enquanto as ucuúbas singram pelo movimento das correntes. "Durante as enchentes de marés vivas, março e abril, especialmente" - assim descreve Paes Loureiro no pequeno glossário de Porantim - [as ucuúbas] “descem boiado o rio". A plasticidade das ucuúbas, que boiam "Por sobre o rio", aciona uma outra dinâmica simbólico-metafórica no poema. O invólucro da semente de ucuúba é constituído por uma película de intensa e estupenda coloração vermelha. O rubro da ucuúba emerge da ruptura da casca globular que envolve a sua semente. A imagem evocada pela poesia é nítida: o intenso vermelho da ucuúba, metaforizando o sangue de Tamar [“amam-se agora/ em chão de paxiúba/ Por sobre o rio/ boiam-se ucuúbas"], simboliza a sexualidade em puro ato. A evocação da ucuúca no Cântico XVII - perspectivada pela emergência do rubro cromatismo do fruto sinaliza uma nova convocação do poema de Lorca. No Romancero gitano, tal como no poema 
de Paes Loureiro, a cor vermelha também está consignada ao cenário do encontro de Amon e Tamar:

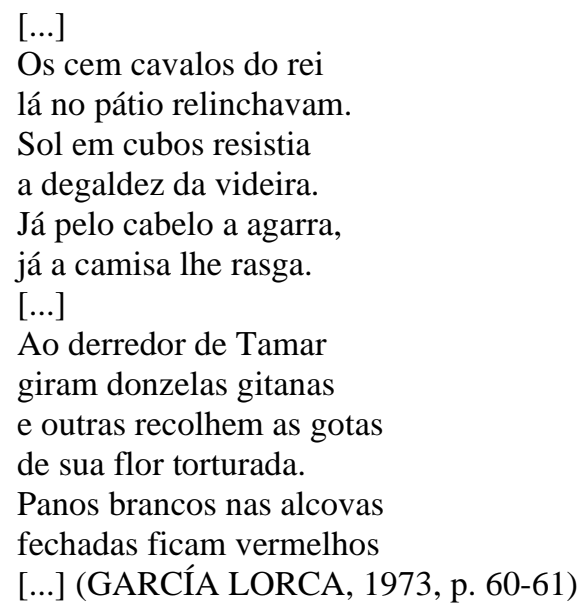

A voluntária presença de Tamar nos aposentos de Amon - assim sugere o poema de García Lorca ["Tamar entrou silenciosa/ na alcova silenciada] - cria um evidente paradoxo com os versos "Já pelo cabelo a agarra,/ já a camisa lhe rasga/ [...] recolhem as gotas/ de sua flor torturada" (GARCÍA LORCA, 1973, p. 60-61), porque estes últimos, à primeira vista, reconstituem de algum modo a cena da violação de Tamar em 2Sm 13, 11-14, inclusive em razão do peso exercido pela narrativa do texto bíblico na recepção do poema. A nevralgia da poesia de García Lorca está concentrada na construção poética “[...] flor torturada”. Em lapidar alusão ao poeta espanhol Antonio Machado, Eladio García C. (1980, p. 37) evoca uma "luta erótica" e não uma "guerra" para a Tamar e o Amon de García Lorca. Se os vestígios da dimensão incestuosa do mito de Tamar e Amon são apagados pelo poema de Paes Loureiro, é possível admitir que os versos

$$
\begin{aligned}
& \text { sucumbem padrenossos } \\
& \text { e heresias } \\
& \text { afogam-se, na tarde, }
\end{aligned}
$$

avemarias (PAES LOUREIRO, 1978, p. 65)

sugerem a inocuidade das orações mais conhecidas nas práticas penitenciais religiosas católicas, porque não se pode imputar qualquer culpa ou pecaminosidade à Tamar e a Amon. Os aludidos versos significam, portanto, a inviolabilidade da sacralidade erótico-originária que recobre os amantes no Cântico XVII, de Porantim. "Si ignorásemos la tradición bíblica”, como bem sublinha Eladio García C., e que se aplicaria tanto ao poema de Paes Loureiro quanto ao de García Lorca, "[...] pasaríamos por alto el incesto" (GARCÍA C., 1980, p. 37). Aparentemente regidos por entes do cosmos, [“Altar mar/[...] em chão de paxiúba"]/ [“A lua gira no céu/ por sobre as terras sem água”], os amantes em Paes Loureiro, tal como em García 
Lorca, tão bem adornados com "encrustes" culturais próprios, tornam-se símbolos da eliminação de todo vestígio da moralidade bíblica (GARCÍA C., 1980, p. 36). Portanto, "sucumbem padrenossos e heresias" ou ainda "sucumbem padrenossos" e "heresias afogam-se, na tarde," ou mesmo "afogam-se, na tarde, avemarias [...]". Qualquer que seja a forma que tal sequência de versos venha a assumir, o poema de Paes Loureiro prima claramente pela desintegração da atmosfera penitencial religiosa católica. O versículo bíblico "Não meu irmão! Não me violentes porque não se procede assim em Israel, não cometas essa infâmia" (2Sm 13, 12), dá voz à Tamar, vítima da violação de Amon, ao tempo em que ecoam os códigos normativo-religiosos [“...porque não se procede assim em Israel”] tão expressivos na sacramoralidade da tradição religiosa judaico-cristã. Na Bíblia, ao contrário dos poemas de Paes Loureiro e García Lorca, a história de Tamar e Amon será sempre a história de um incesto.

\section{No poema, um outro mito}

Embora a busca pela Bíblia e por García Lorca revele a enorme erudição tão peculiar à criação artística de Paes Loureiro, impomo-nos à tarefa de pensar em outras correspondências - para além do nítido quadro referencial já constituído pelo poeta - que eventualmente participariam da tessitura do Cântico XVII, de Porantim. Propomos, portanto, que o poema de Tamar e Amon, de Porantim, seja também considerado uma variante do mito amazônico de Tambatajá, que segundo Paes Loureiro "reproduz na Amazônia o percurso dos grandes amorosos" (PAES LOUREIRO, 1995, p. 276). E prossegue o poeta: “Tambatajá é a lenda do amor impossível de ser superado [...]" (PAES LOUREIRO, 1995, p. 276). Tomando como horizonte o Cântico XVII e por contraste o mito de Tambatajá, teríamos aí um caso exemplar de passagem do mito à poesia, caracterizando, portanto, aquilo que o próprio Paes Loureiro chamou conversão semiótica.

Entendo como conversão semiótica - assim sublinha Paes Loureiro - o movimento de passagem de objetos ou fatos culturais de uma situação cultural à outra, pelo qual as funções [funções desses objetos ou fatos culturais] se reordenam e se exprimem nesta nova situação cultura, sob a regência de uma outra dominante (PAES LOUREIRO, 2008, p. 46).

Assim:

A conversão semiótica pode ser observada, por exemplo, na criação artística, no trajeto antropológico, nos processos de tradução, nas transferências de campo cultural. [...] a denominação de conversão semiótica a esta passagem modificadora da qualidade dos signos, resultante do cruzamento ou inversão de funções situadas no alto e no baixo de um fenômeno cultural determinado, parte do movimento dialético 
de rearranjamento dessas funções, como resultado de alteração da dominante em um contexto cultural ou passagem a outro contexto (PAES LOUREIRO, 2008, p. 47).

Em nossa percepção, a presença de Tambatajá no Cântico XVII expressaria de modo emblemático um tipo de conversão semiótica caracterizada pela poetização do mito por meio do poema. Se o texto de 2 Sm 13 se constitui como uma narrativa exemplar da violação, da violência, e que, portanto, consigna ao mito do amor entre irmãos a interdição enquanto seu sentido fundamental, o poema de Paes Loureiro, em diametral oposição, reordena a "função prática" [interditória e moralizadora] do mito bíblico, isto é, reordena a dominante do mito [“...porque não se procede assim em Israel”], posto que a desloca ao transfigurar não só o próprio mito, mas também o sentido do interdito numa poética do amor incondicional. A variante sob a qual renasce Tamar e Amon é antes governada pela pulsão erótica. Tal perspectiva não pode em absoluto ser deduzida do texto bíblico. Sob a admissão de que o Cântico XVII seja um tipo de variante de Tambatajá, o mito do amor entre irmãos, na poética amazônica de Paes Loureiro, se rejuvenesce, porque dissipa a entonação trágica, moral e prescritiva do texto bíblico ao tempo em que assimila e expressa a incondicionalidade e a ingovernabilidade que o amor erótico reivindica [“[...] onde/ Tamar e Amon"/ Amam-se agora"]. Ancorados na paisagem do incessante e evanescente movimento águas, ou seja, inscritos na ordem mesma da cosmologia amazônica (face ostensiva da Amazônia profunda), Tamar e Amon, pelo poema, imortalizam o seu ato de amor. Uso em proveito do Cântico XVII o que o próprio Paes Loureiro dissera acerca Tambatajá: “A narrativa dessa lenda é a de um amor cego poetizado" (PAES LOUREIRO,1995, p. 281).

Visto por este prisma, Paes Loureiro, por meio de sua criação artística, reconfigura a significação do mito dos irmãos que se amam em uma variante amazônica. Essa reconfiguração poético-amazônica de um “mito de referência" (LÉVI STRAUSS, 2010) para diversas culturas, ao circular de forma transfigurada (a começar pelo próprio ambiente cultural ao qual esta reconfiguração está consignada), por certo descentra o sentido majoritário e tradicionalmente assumido pelo mito. De acordo com as fontes mais conhecidas, sabemos que Tambatajá não narra propriamente o mito dos irmãos que se amam. Abaixo, um pequeno fragmento de Tambatajá ${ }^{11}$.

Uma índia macuxi fugiu da maloca bonita, no rio Surumu, com o filho de um tuxaua taulipangue.

Os pais e parentes dela ficaram zangados. E os pais e parentes dele, também.

\footnotetext{
${ }^{11}$ Paes Loureiro recorre à obra Moronguêtá. Um Decameron indígena (1967), de Nunes Pereira, como fonte da narrativa de Tambatajá.
} 
Mas a moça macuxi e moço taulipangue não se importaram com a zanga dos velhos, porque se queriam muito na força do seu desejo.

E foram morar nas bandas da Serra da Lua, do outro lado do rio Tucutu, onde viviam uns parentes dele.

E nunca se separaram.

Se ele ia pescar, ela ia também.

Se ela ia banhar-se, ele ia também.

[...] (PAES LOUREIRO, 2000, p. 264)

A tentativa de decifração de um mito de referência - aqui visitado a partir de duas de suas mais conhecidas variantes [a do amor entre irmãos e a do amor incondicional] - sob a evidência de sua circularidade em diversas culturas - não pode somente encontrar na existência de uma isomorfia entre os documentos culturais disponíveis a única chave interpretativa. A aproximação de Tambatajá ao Cântico XVII se deve antes à transparente polimorfia que se revela no conteúdo de cada um desses documentos poéticos da cultura amazônica. O Cântico XVII retoma o mito do amor entre os irmãos; Tambatajá, por sua vez, recupera o mito do amor incondicional que sofre com os interditos (a reprovação com a qual a índia macuxi e o índio tuxaua taulipangue se confrontam em suas respectivas tribos anuncia a emergência de um interdito de ordem familiar neste mito). Nestes dois tecidos poéticos amazônicos não prevalecem nenhuma das duas variantes dos interditos. Este é o ponto central de aproximação. O encontro entre o mito e o poema - o que há pouco chamamos de passagem do mito ao poema - o que o confere ancestralidade ao mito de Tambatajá em relação ao Cântico XVII - se dá pela forja e pela projeção de imagens da incondicionalidade do amor por meio de suas respectivas teias poéticas.

\section{Considerações finais}

O Cântico XVII de Porantim recria uma imagem do humano em estado originário. Nela, o erótico, evocado emblematicamente a partir de Tamar e Amon, apresenta-se como uma força indomável que dispensa este humano - em razão de sua condição originária - de qualquer imputação de natureza religiosa. A evanescente paisagem dos rios, na qual repousam solenemente Tamar e Amon, faz do poema uma fisiografia de um paraíso amazônico tecido poeticamente. A belíssima inscrição desta evanescente paisagem no Cântico XVII não é um aceno positivo aos que aderem à categoria do exótico como chave de compreensão da cultura e da natureza da "Pátria da água", mas antes uma exaltação poética de sua incontestável exuberância. A reconfiguração poética de Tamar e Amon, sob o signo da força do erótico, se realiza por meio de uma costura complexa de tecidos de outros chãos, de outras culturas. $\mathrm{O}$ 
Cântico XVII é entoado a partir da matéria prima que o universo amazônico dispõe ao poetanativo, mas também a partir do que ele transporta de outros substratos culturais, de outros chãos. Na paisagem transfigurada em linguagem, a poesia de García Lorca, a narrativa bíblica de $2 \mathrm{Sm}$ 13 e Tambatajá - visto que o poeta faz ressoar no Cântico XVII de Porantim toda expressividade erótica tão presente na versão taulipangue deste mito do amor - são tecidos que compõem o poema de Paes Loureiro e que tornam a mitologia amazônica mais rica e complexa.

É importante sublinhar, por fim, que a reação esboçada pelo poema a um traço específico da religiosidade católica - porque sugere de modo sutil a inocuidade do ato de se rezar "padrenossos" e "avemarias" no eventual cumprimento de penitências ["sucumbem padrenossos/ e heresias/ afogam-se, na tarde,/ avemarias"] - não se ajusta propriamente à percepção de que a linguagem literária [poética por assim dizer] se presta de modo pacífico ao ofício da descrição objetiva de um quadro religioso culturalmente circunscrito. Esta afirmação, todavia, não subtrai do poema o fio que pode nos levar à constatação da expressiva presença de múltiplas religiosidades católicas em toda Amazônia. Embora o poema não renuncie a possível tarefa de ser também um grito, isto é, tornar-se um veículo de crítica, a presença de traços religiosos em seus versos seria antes fruto de uma escolha artística daquele que tem na palavra, “infinitamente trabalhada" (BARTHES, 2007) a matéria prima do seu ofício. Tendo “consciência da palavra", como bem sublinhou Roland Barthes (2007), o escritor "é aquele para quem", de modo incondicional, "a linguagem constitui problema" e "que experimenta a sua profundidade". Assim é Paes Loureiro com a sua poesia.

\section{REFERÊNCIAS}

BACHELARD, Gaston. L'eau et les rêves. Essai sur l'imagination de la matière. Paris: Librairie José Corti, 1942.

BARTHES, Roland. Crítica e verdade. 3. ed. São Paulo: Perspectiva, 2007.

BIBLÍA DE JERUSALÉM. São Paulo: Paulus, 2000.

ELIADE, Mircea. Imagens e símbolos. Ensaio sobre o simbolismo mágico-religioso. São Paulo: Martins Fontes, 1991.

ELIADE, Mircea. Tratado de história das religiões. 4. ed. São Paulo: WMF Martins Fontes, 2010.

GARCÍA C., Eladio. Interpretación del romance Thamar y Amnón y sus incrustes gongorinos. Revista Chilena de Literatura, Santiago, n. 16/17, pp. 25-39, out./abr., 1980/1981. 
GARCÍA LORCA, Federico. Romanceiro gitano e outros poemas. Rio de Janeiro: J. Aguilar; Brasília: INL, 1973.

GENETTE, Gérard. Palimpsestes: la littérature au second degré. Paris: Éditions du Seuil, 1982.

LÉVI-STRAUSS, Claude. O cru e o cozido. 2. ed. São Paulo: Cosac \& Naify, 2010.

PAES LOUREIRO, João de Jesus. Porantim. Rio de Janeiro: Civilização Brasileira, 1978.

PAES LOUREIRO, João de Jesus. Deslendário. Rio de Janeiro: Civilização Brasileira, 1981.

PAES LOUREIRO, João de Jesus. Altar em chamas. Rio de janeiro: Civilização Brasileira, 1983.

PAES LOUREIRO, João de Jesus. Cantares amazônicos. São Paulo: Roswitha Kempf Editores: 1985.

PAES LOUREIRO, João de Jesus. Cultura amazônica: uma poética do imaginário. Belém: CEJUP, 1995.

PAES LOUREIRO, João de Jesus. Obras reunidas. São Paulo: Escrituras Editora, 2000. vol. 4.

PAES LOUREIRO, João de Jesus. A arte como encantaria da linguagem. São Paulo: Escrituras Editora, 2008.

STOLL, Émilie et al. Paisagens evanescentes: estudos sobre a percepção das transformações das paisagens pelos moradores dos rios Amazônicos. Belém: NAEA, 2019.

SERVIÇO SOCIAL DO COMÉRICO. Conversa sobre as artes. Rio de Janeiro: SESC, 2014. vol. 1.

MAUÉS, Raymundo Heraldo. Um aspecto da diversidade cultural do caboclo amazônico: a religião. Estudos Avançados, São Paulo, v. 19, n. 53, pp. 259-274, jan./abr. 2005.

MAUÉS, Raymundo Heraldo. Revista Anthropológicas, Recife, ano 11, v. 18, n. 2, pp. 153182, jul./dez. 2007.

NUNES, Paulo Jorge Martins. Útero de areia, um estudo do romance Belém do Grão-Pará, de Dalcídio Jurandir. Tese de Doutorado, Programa de Pós-Graduação em Letras, PUC-MG, Belo Horizonte, 2007.

PIZARRO, Ana. Imaginario y discurso: la Amazonía. Revista de Crítica Literaria Latinoamericana, Lima-Hanover, ano 31, n. 61, pp. 59-74, jan./jun. 2005.

Recebido em 21/05/2020. Aceito em 31/08/2020. 